\title{
Unilateral pulmonary oedema
}

\author{
Raghav Bhargava, ${ }^{\oplus 1}$ Richard Cowell ${ }^{2}$
}

${ }^{1}$ Internal Medicine, Wrexham Maelor Hospital, Wrexham, Wales, UK

${ }^{2}$ Cardiology, Wrexham Maelor Hospital, Wrexham, Wales, UK

\section{Correspondence to}

Dr Raghav Bhargava, raghavbhargava90@gmail.com

Accepted 13 May 2019

\section{DESCRIPTION}

A 69-year-old chef presented to the emergency department with sudden onset shortness of breath, central chest pain and haemoptysis. His medical history included hypertension, type 2 diabetes mellitus, left total hip replacement and an anterior ST elevation myocardial infarction which required rescue percutaneous coronary intervention to the proximal left anterior descending (LAD) coronary artery. Physical examination revealed a temperature of $38.3^{\circ} \mathrm{C}$, blood pressure of $142 / 101 \mathrm{~mm} \mathrm{Hg}$, heart rate of 92 beats/ min and oxygen saturations of $96 \%$ on high-flow oxygen through a reservoir mask. The patient also had left-sided lung crackles with increased vocal fremitus. The chest X-ray (figure 1) showed left-sided air space opacification and a clear lung on the right side. The ECG showed sinus rhythm with poor $\mathrm{R}$ wave progression in the chest leads. The patient clinically responded to intravenous furosemide. A CT angiography of the pulmonary arteries did not exhibit a pulmonary embolus or any pleural effusions. Transthoracic echocardiography (TTE) demonstrated a moderately impaired left ventricular systolic function with an estimated ejection fraction of $30 \%-35 \%$ and mild aortic regurgitation. Blood tests revealed an elevated C-reactive protein of $237 \mathrm{mg} / \mathrm{L}$ and a troponin I rise of $32 \mathrm{ng} / \mathrm{L}$ at presentation to $1327 \mathrm{ng} / \mathrm{L} 3$ hours later. Unilateral pulmonary oedema is an uncommon clinical presentation. Distinguishing it from unilateral pneumonia is difficult. There are many reasons for acute phase reactants to rise including acute coronary syndrome and pneumonia; hence, the patient was started on intravenous antibiotics to

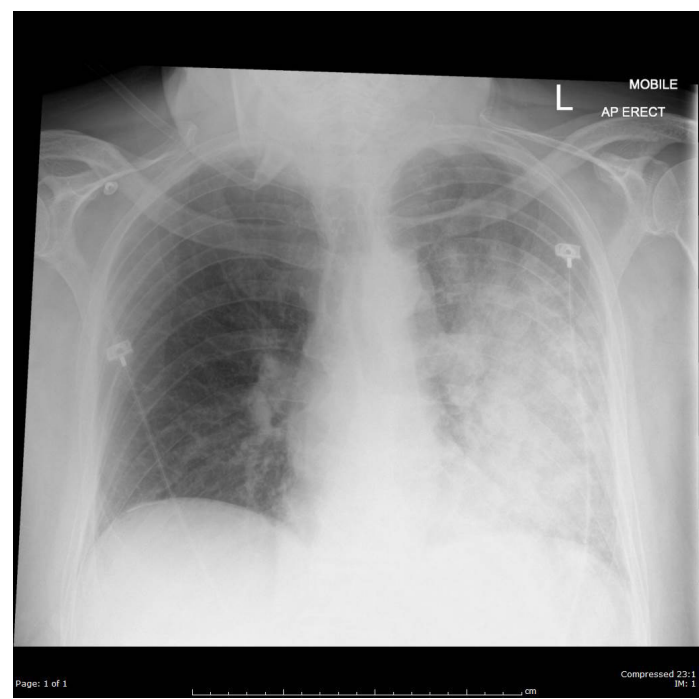

Figure 1 Chest radiograph on admission.

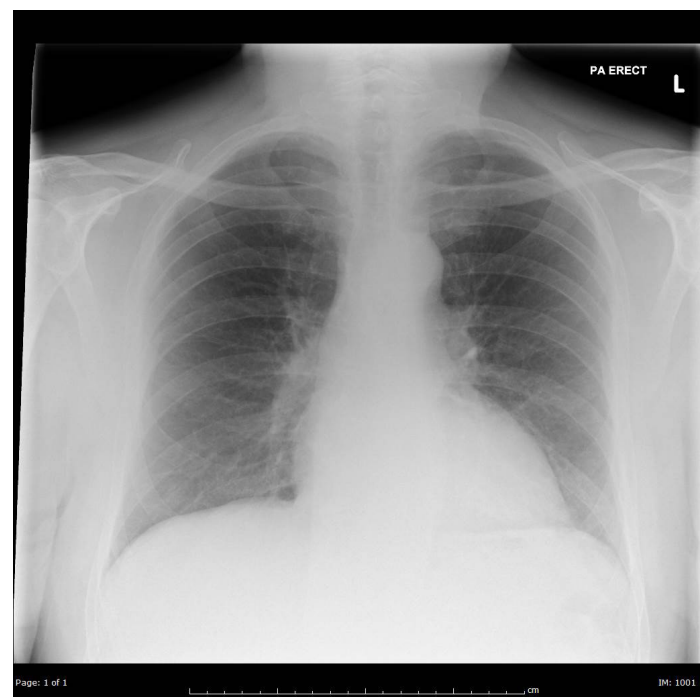

Figure 2 Chest radiograph after angioplasty.

initially cover for pneumonia. Given the significant troponin elevation, he was also administered aspirin, clopidogrel and fondaparinux. Subsequently, coronary angiography revealed an obstruction in the diagonal branch of his LAD requiring two drug-eluting stents. Repeat chest radiography after angioplasty (figure 2) showed rapid resolution of the pulmonary infiltrates suggesting unilateral pulmonary oedema. The antero-lateral papillary muscle of the mitral valve is supplied by the diagonal branch of the LAD coronary artery. During the early phases of a myocardial infarction involving the LAD coronary artery transient mitral regurgitation (MR) is common and can cause haemodynamic compromise. Although our patient's TTE did not demonstrate any chordae tendineae or papillary muscle rupture leading to overt MR, he probably did have some ischaemia related papillary muscle dysfunction. This caused the flow to be directed to the upper left pulmonary vein, leading to an increased pulmonary capillary wedge pressure on that side and subsequently unilateral pulmonary

\section{Learning points}

- A diuretic responsive lung opacification is most likely to be pulmonary oedema.

- A common presentation such as pulmonary oedema is normally bilateral. However, rarely, it may be unilateral.

- Unilateral pulmonary oedema is most commonly due to severe mitral regurgitation. Nevertheless, acute coronary syndrome may present this way. 


\section{Images in...}

oedema. Another reason to suspect there may have been ischaemia-induced MR due to an acute coronary event is that eccentric jets of the transient MR led to a sudden increase in left atrial pressure which back flowed to the pulmonary circulation causing disruption of the pulmonary capillaries and resulting in haemoptysis. The patient made a rapid recovery with diuretics, antiplatelet medication and coronary angioplasty.
Contributors RB and RC made substantial contributions to the conception and design of the work. RB was involved in drafting the work and revising it critically for important intellectual content. RB approved the final version to be published.

Funding The authors have not declared a specific grant for this research from any funding agency in the public, commercial or not-for-profit sectors.

Competing interests None declared.

Patient consent for publication Obtained.

Provenance and peer review Not commissioned; externally peer reviewed.

Copyright 2019 BMJ Publishing Group. All rights reserved. For permission to reuse any of this content visit

https://www.bmj.com/company/products-services/rights-and-licensing/permissions/

BMJ Case Report Fellows may re-use this article for personal use and teaching without any further permission.

Become a Fellow of BMJ Case Reports today and you can:

- Submit as many cases as you like

Enjoy fast sympathetic peer review and rapid publication of accepted articles

Access all the published articles

Re-use any of the published material for personal use and teaching without further permission

Customer Service

If you have any further queries about your subscription, please contact our customer services team on +44 (0) 2071111105 or via email at support@bmj.com.

Visit casereports.bmj.com for more articles like this and to become a Fellow 